\title{
THE IMMUNITY OF CONGRESSIONAL SPEECH-ITS ORIGIN, MEANING AND SCOPE
}

\author{
By LÉoN R. YANKWICH†
}

The Report of a sub-committee of the Committee on Foreign Relations of the United States Senate, filed on July 20, 1950, denouncing in unusually strong language the charges made by one of the Senators, Senator Joseph R. McCarthy of Wisconsin, ${ }^{1}$ called attention once more to the constitutional immunity enjoyed by the members of the Senate and House of Representatives. ${ }^{2}$ The facts which led to the Report are well known. In several public addresses and in a senatorial discussion on foreign policy, Senator McCarthy had charged Owen Lattimore with being "the chief architect" of the American foreign policy in China and "the top Russian espionage agent in the United States", and accused the State Department of harboring known Communists.

Owen Lattimore is a professor at Johns Hopkins University, Baltimore, Maryland, and the director of its School of International Relations. His wide knowledge and experience with Asiatic affairs has made him an expert on Asiatic countries, especially China and the lands between China and Russia. $\mathrm{He}$ is the author of several books on those lands. As a writer and authority on the subject, he had acted as consultant on various missions. As a political adviser to the Government of Chiang-Kai-Shek in 1941-1942, his recent views on the United States Government's policy and attitude towards the Government of China have been the subject of much discussion. After Senator McCarthy's accusation was made, Lattimore and his friends took up the challenge. As a result the Chairman of the Senate Committee on Foreign Relations appointed a sub-committee headed by Senator Millard E. Tydings of Maryland, which, on July 20, 1950, made a majority Report entirely exonerating Lattimore and denouncing the

$\dagger$ LL. B., Williamette University, 1909, LL.D., Loyola University, 1929; Member of the bars of California and Oregon; Formerly, Lecturer on Pleading and Practice, Loyola University; Formerly, Judge, Superior Court of Los Angeles County; Currently, Judge, Federal District Court, Southern District, California. Author, IT's Libet or Contempt If You Print It (1949); THe New Frderal Rules of Criminal Procedure (1946); The New Federal Rules of Civil Procedure (1938); Marriage and Divorce (1937); The Constitution and the Future (1936) ; Notes on Common Law Pleading (1930) ; Essays in the Law of Libel (1929); Handbook of California Pleading and Procedure (1926); The Limitations of Laze and Judicature, 99 U. OF PA. L. REv. 171 (1950); various articles in legal periodicals.

1. Sen. Rep. No. 2108, 81st Cong., 2d Sess. (1950).

2. U.S. Const. Art. I, $\S 6, \mathrm{Cl} .1$. 
charges as unfounded. One of the minority, Senator Henry Cabot Lodge, Jr., also stated in his generally dissenting special report that the charges against Lattimore and the State Department had not been proved. $^{3}$

On the heels of the Report, in September, 1950, came another senatorial attack. This time, Senator Andrew F. Schoeppel of Kansas made serious charges against the loyalty of the Secretary of the Interior, Oscar C. Chapman. The quick disproval of the charges by the Secretary and other sworn witnesses before the Senate Committee, headed by Senator Joseph C. O'Mahoney of Wyoming, and their characterization of the accusations as lacking any foundation ended the controversy very quickly.

Accusations of this character deserve the name applied to them recently by a writer, "assassination [of character] by guesswork". 4 They unloose-to use the language of the protest of a small group of Senators, headed by Senator Margaret Chase Smith of Maine-cthe four horsemen of calumny-fear, ignorance, bigotry, and smear." So it is fitting to discuss the origin, nature and scope of the constitutional immunity which attaches to the speech of members of the United States House of Representatives and Senate.

\section{HISTORICAL ORIGIN}

Absolute freedom of speech for members of legislative assemblies is one of the fundamentals of parliamentary government, accepted as

3. In his address on the floor of the Senate, in presenting the Report, Senator Tydings summed up the result in Lattimore's case in these words:

"With reference to Lattimore, four members of the committee who saw fit to file reports-the majority reports and the one by the Senator from Massachusetts (Mr. Lodge) - say the charges are not proved" 96 Cong. Rec. 10867 (July 20, 1950). (Emphasis added)

4. Weeks, Atlantic Monthly, Sept., 1950, pp. 73, 74. In Christian Science Monitor, September 14, 1950, p. 1, col. 3, under a Washington date line, Roland Sawyer, speaking on "Congressional Privilege-and Its Abuse," and commenting on the failure of the charges against Secretary Chapman and their relation to the charges of Senator McCarthy against Owen Lattimore and the State Department, wrote:

"From the start of this case, the issue has been the use and misuse of senatorial privilege. The constitutional right of a senator or representative to speak his mind on the Senate or House floor without fear of lawsuit reached the climax in the McCarthy case.

"Where Senator Joseph R. McCarthy (R) of Wisconsin caused men to fear prosecution without proof, the doubting Senator Schoeppel so far has provided almost comic relief. Unwittingly, he has provided something better. He has given sensitive senators opportunity to review the value of privilege in a calmer mood than was possible during the severe strain of the McCarthy investigation.

"Republicans as well as Democrats talked privately then about the misuse of privilege, but seemed powerless to do anything. Not so this time. The moment is not too soon to protect senatorial privilege which, properly used, can be a valuable function. Even more, it is not too late to protect private citizens from its unwarranted, sometimes unspeakably damaging, misuse." 
such by all governments which recognize the parliamentary system and seek to insure its independence. The scope of this privilege was stated by Thomas Jefferson in a petition addressed, in May, 1797, to the Virginia House of Delegates, in which he took exception to the presentment made by the Grand Jury of the Circuit Court at Richmond, Virginia, which had criticized some members of Congress, including one from Virginia, for disseminating what they called "unfounded calumnies against the happy government of the United States." Jefferson wrote:

"that in order to give to the will of the people the influence it ought to have, and the information which may enable them to exercise it usefully, it was a part of the common law, adopted as the law of this land, that their representatives, in the discharge of their functions, should be free from the cognizance or coercion of the coordinate branches, Judiciary and Executive." 5

As Jefferson well stated, the immunity originated in England. It developed as a privilege asserted by the Parliament of England against the prerogatives of the King, in order to fulfill its function as an independent branch of Government. It came out of the struggle between King and Parliament for supremacy. That is especially true of the lower House of Parliament, because the House of Lords, in its inception, being considered "a court", enjoyed the right to speak freely on governmental affairs without punishment by the King. But the assertion of this right by the Commons was challenged repeatedly by the King, and only occasionally acknowledged. As is the case with other incidences of constitutional history, many writers on the subject have sought early precedents for the assertion of this right. Some refer to a case dating back to Richard II (1396-1397). A member of the Commons, Thomas Haxey, was condemned in Parliament as a traitor for having offered a bill to reduce the expenditures of the royal household. The death sentence was not carried out during Richard's reign. On the accession of his successor, Henry IV, Haxey petitioned the King in Parliament to reverse the judgment as being

"encountre droit et la course quel avoit este devant en Parlement" (against the law and system which had existed before in Parliament).

The petition was granted in 1399. And, in the same year, the Commons petitioned the King directly to reverse the judgment. This was done. And the judgment was annulled.

5. Luce, Legislative Assemblies 516-518 (1924); 7 Writings of Thomas JEFFERSON 158 (Ford ed. 1896). 
A more significant case arose in the reign of Henry VIII (in 1512). Richard Strode, a member of Parliament, had been prosecuted in the courts and imprisoned for having proposed bills to regulate the Cornwall tin industry. Parliament passed an act annulling the judgment against him and declared void all suits and proceedings against Strode and every other member of Parliament

"for any bill, speaking, or declaring of any matter concerning the Parliament, to be communed and treated of, be utterly void and of none effect." 6

But, notwithstanding this recognition, the right of free speech continued to be considered, more or less, as an act of grace on the part of the King. For a long time, English courts could not agree whether the Act of 1512 was general or special. And the real recognition of the right to immunity for parliamentary speech or action came through the request made by the Speaker of the House of Commons,- repeated at the beginning of every session of Parliament,-which the King granted, of the right to speak with impunity, along with other rights, such as access to the King, and the like.

The first of these requests was made and granted in 1541. Under the Tudor Kings, the royal prerogatives dominated, although strong voices were heard asserting the right of the Commons during the absolute reign of Elizabeth. The struggle between the Stuart Kings and Parliament, which brought on, first, the Commonwealth, then the Restoration, and which culminated in what the English call "the glorious Revolution" of 1688 , led to the first unequivocal legislative recognition in England of legislative immunity for parliamentary speech.

An interesting prelude to this final acknowledgment occurred in Parliament in December, 1641. Charles I had objected, on December 14, 1641, in his speech to Parliament, to the contents of a bill, stating that he would not approve it if it came to him. The entire Parliament, in its answer to the speech, asserted the right to be free of the domination of the King and to speak freely without incurring his displeasure:

"Amongst other the Priviledges of Parliament; They do, with all dutiful reverence to your Most Excellent Majesty, declare that it is their ancient and undoubted Right; 'That your Majesty ought not to take notice of any matter in agitation and debated in either of the Houses of Parliament, but by their information

6. May, Parliamentary Practice 47-52 (14th ed. 1946); 3 Redlich, The Procedure of the House of Commons 42 et seq. (Steinthal's transl. 1908); Wittke, The History of Parliamentary Privilege 23-32 (1921); Clarke, Parliamentary Privilege in the American Colonies 1-13 (1943). 
and agreement; and that your Majesty ought not to propound any Condition, Provision, or Limitation, to any Bill, or Act, in debate, or preparation, in either House of Parliament; or to Manifest, or declare, your consent, or dissent, approbation, or dislike of the same, before it be presented to your Majesty in due course of Parliament; and that every particular Member of either House hath free libertie of speech to propound, or debate, in any matter according to the order and course of Parliament; and that your Majesty ought not to conceive displeasure against any man for such opinions and propositions as shall be delivered in such debate, it belonging to the several Houses of Parliament respectively to judge and determine such errours and offences in words or actions as shall be committed by any of their Members in the handling, or debating, any matters depending.'

"They doe further declare, that all the Priviledges above mentioned have been lately broken, to the great sorrow and grievance of your most humble and faithful subjects, in that Speech which Your Majestie made in Parliament, to both Houses, upon Tuesday last the fourteenth of this present moneth of December, in that your Majesty did therein take notice of a Bill for impressing of Souldiers being in agitation in the said Houses, and not agreed-upon: and that your Majesty did therein offer a Salvo Jure, or provisional Clause, to be added to that Bill before it was presented to your Majesty by the consent of both Houses, and did at the same time declare your displeasure against such persons as had moved some doubt, or question, concerning the same Bill. All which they doe affirm and declare to be against the ancient, lawful, and undoubted Priviledges and Liberties of Parliament." 7

The Bill of Rights, granted by William and Mary in 1688, in Section 19, gave ultimate recognition to the right in these words:

"That the freedom of speech, and debates or proceedings in Parliament, ought not to be impeached or questioned in any court or place out of Parliament."

And, subject to the extensions and limitations to be noted later in the discussion, this is the form in which the right exists today.

\section{The Diffusion of the Principle}

Just as all parliamentary institutions find their inspiration in English Parliament, so is this immunity of members of legislative bodies

7. May, History of the Parliaments of England 234-235 (1812). Before the enactment of the Bill of Rights, on December 11,1667, a Report of the Conference of the Parliament on the effect of the statute of 1512 stated:

"An act of parliament cannot disturb the state; therefore the debate that tends to it cannot, for it must be propounded and debated, before it can be enacted."

3 REDLICH, op. cit. supra note 6, at 48 . 
for what they speak in the legislative halls traceable to English precedent. Modern constitutional governments, wherevèr established, perceived, early in their development, the value of this principle. In France, parliamentary immunity was introduced by resolution adopted by the National Assembly in 1789 and reasserted in subsequent constitutions. Other continental European countries followed the French pattern. The privilege was granted by the Belgian Constitution in 1839, by the Prussian Constitution of 1850, and the Constitution of the German Empire (the First Reich) of 1871. Indeed, the general liberal movement which dominated Europe in 1848 spread parliamentary and democratic ideals to many countries, European and American, which adopted this immunity along with other liberal, democratic principles. The First World War aided the adoption of this principle in the liberal constitutions which, everywhere, except in Soviet Russia, followed in its wake. Provisions embodying it are found in the German Republican (Weimar) Constitution of 1919 (Article 36) $;^{8}$ the Austrian Constitution of 1920 (Article 57), which applies to local Diets also (Article 96 ) $;^{9}$ the Constitution of Greece of $1927 ;^{10}$ the Constitution of Ireland of $1921 ;{ }^{11}$ the Constitution of Roumania of 1923 (Article 54); ${ }^{12}$ the Constitution of Czechoslovakia of 1928 (Article 23): ${ }^{13}$ and the Constitution of Turkey of 1924 (Article 17$)^{14}$ and others.

In colonial America, the right was recognized in the various Houses of Burgesses or Assemblies. ${ }^{15}$ This was in the spirit of the attitude of the colonists who consistently claimed for themselves, as individuals and for their instrumentalities of government, the rights belonging to all Englishmen. And when the Federal Constitution came to be written, it was to be expected that it would give recognition to legislative immunity. This was done by providing that

". . . for any Speech or Debate in either House, they [the Senators and Representatives] shall not be questioned in any other Place." 16

All the state constitutions, adopted after the establishment of independence, affirmed this principle. Later, the more modern constitu-

8. Mirkine-Guetzevitch, Les Constitutions de L'Europe Nouvelle (1928).

9. Id. at 140 (Federal), 149 (Diets).

10. Id. at 202 .

11. Id. at 224 .

12. Id. at 285 .

13. $I d$. at 329 .

14. Id. at 352 .

15. ClaRKE, op. cit. supra note 6 , at 61 et seq.

16. See note 2 supra; 1 Cooley, Torrs $\$ 154$ (4th ed. 1932), asserts that "[the protection] exists independent of such a declaration as a necessary principle in free government." 
tions reaffirmed it. Typical of the broad scope which the immunity took is Article 21 of the Declaration of Rights of the Constitution of Massachusetts of 1780 :

"The freedom of deliberation, speech and debate, in either house of the legislature, is so essential to the rights of the people, that it cannot be the foundation of any accusation or prosecution, action or complaint, in any other court or place whatsoever." 17

And, generally, the right exists in every state in the Union, either by constitution, legislative enactment, or as a part of the accepted common law. ${ }^{18}$

\section{The Meaning and Scope of the Immunity}

It is plain that the immunity began as a protection against executive interference with the individual legislator. It broadened so as to become an absolute shield against all outside interference with the legislative process itself. And this, not so much as a protection to the legislator as an essential condition for the existence and full development of the legislative process. Significantly, the Massachusetts Constitution considered fredom for legislative deliberation, speech and debate "essential to the rights of the people." 19 Rightly. For, under a democratic regime, legislation is-theoretically at least-the expression of the public will and the means of expressing that will in laws, which the people, by the very nature of democratic assent, are bound to obey. By keeping the legislator free from outside domination, executive or other, by eliminating the threat of interference through prosecution, civil or criminal, the independent exercise of the rights of the people, through legislation, is safe-guarded. With the development of the law of defamation, it was natural that, either by legislation or judicial construction, what had begun as a defensive measure against executive interference should extend to all attempts to curtail freedom of legislation by court action. As a result the privilege became absolute, conditioned only by the fact that what is said or spoken be done in the course of legislative proceedings.

Some early cases in England sought to delimit strictly the scope of parliamentary debate and action. One famous English decision declined to extend the parliamentary privilege to private publication of the debates. ${ }^{20}$ But at the present time, both in England and in the

17. MASS. Const., Declaration of Rights, Art. XXI. 37 (1941).

18. See Cal. Civ. Code, \$ 47 (1941) ; Kelly v. Daro, 47 Cal.App.2d 418, 118 P.2d

19. See note 17 supra.

20. Stockdale v. Hansard, 9 A. \& E. 1, 112 Eng. Rep. 1112 (1839). It required an act of Parliament to overcome the effect of this decision: $3 \& 4$ Vict., c. 9 (1840). 
United States, the privilege is absolute. It extends not only to the debates themselves, but also to reports of the debates, to actions before committees of legislative bodies, to petitions addressed to the legislative bodies or to any of their committees, and to witnesses appearing or testifying before such committees.

A late English authority sums up the state of the law in England in this manner:

"The absolute privilege of statements made in debate is no longer contested, but it may be observed that the privilege which formerly protected Members against action by the Crown now serves largely as protection against prosecution by individuals or corporate bodies. Subject to the rules of order in debate (see Chap. XVIII), a Member may state whatever he thinks fit in debate, however offensive it may be to the feelings, or injurious to the character, of individuals; and he is protected by his privilege from any action for libel, as well as from any other question or molestation." 21

This is also the present rule in the United States. ${ }^{22}$

In studying the evolution of the principle and reasons which the courts have given for the protecting of the privilege, it is quite apparent that courts were not so much interested in condemning calumny as in protecting the freedom to legislate, which they deemed essential-in the language of the Massachusetts Constitution- "to the rights of the people". Lord Chief Justice Denman, in the case already referred to, ${ }^{23}$ while limiting the application of the immunity to outside publications, nevertheless conceded its full application to whatever is essential to legislation:

"Thus the privilege of having their debates unquestioned, though denied when the members began to speak their minds freely in the time of Queen Elizabeth, and punished in its exercise both by that princess and her two successors, was soon clearly perceived to be indispensable and universally acknowledged. By consequence, whatever is done within the walls of either assembly must pass without question in any other place. For speeches made in Parliament by a member to the prejudice of any other person, or hazardous to the public peace, that member enjoys complete immunity. For any paper signed by the Speaker by order of the House, though to the last degree calumnious, or even if it brought

21. May, Parliamentary Practice 51 (14th ed. Campion 1946); see Dillon v. Balfour, 20 L.R. Ir. 600 (1887); see GATLEY, Libel and SLANDER 211-213 (3rd ed. O'Sullivan 1938).

22. Yankwich, It's LtBel or Contenpt If You Print It 292 (1950); 33 Ax. JuR., Libel and Slander, $\$ 1142-143 ; 53$ C.J.S., Libel and Slander, \$ 105; REstatenent, ToRts, \$590 (1938).

23. Stockdale v. Hansard, 9 A. \& E. 1, 113-114; 112 Eng. Rep. 1112, 1156 (1839). 
personal suffering upon individuals, the Speaker cannot be arraigned in a Court of Justice."

In an early Massachusetts case, the immunity was given the broadest scope:

"These privileges are thus secured, not with the intention of protecting the members against prosecutions for their own benefit, but to support the rights of the people, by enabling their representatives to execute the functions of their office without fear of prosecutions, civil or criminal. I therefore think that the article ought not to be construed strictly, but liberally, that the full design of it may be answered. I will not confine it to delivering an opinion, uttering a speech, or haranguing in debate; but will extend it to the giving of a vote, to the making of a written report, and to every other act resulting from the nature, and in the execution, of the office; and I would define the article as securing to every member exemption from prosecution, for every thing said or done by him, as a representative, in the exercise of the functions of that office, without inquiring whether the exercise was regular according to the rules of the house, or irregular and against their rules. I do not confine the member to his place in the house; and I am satisfied that there are cases in which he is entitled to this privilege, when not within the walls of the representatives' chamber." 24

This latitudinarian view was adopted by the Supreme Court of the United States in a leading case, in interpreting the federal constitutional provision:

"Mr. Justice Story (sect. 866 of his Commentaries on the Constitution) says: "The next great and vital privilege is the freedom of speech and debate, without which all other privileges would be comparatively unimportant or ineffectual. This privilege also is derived from the practice of the British Parliament, and was in full exercise in our colonial legislation, and now belongs to the legislation of every State in the Union as matter of constitutional right.'

It seems to us that the views expressed in the authorities we have cited are sound and are applicable to this case. It would be a narrow view of the constitutional provision to limit it to words spoken in debate. The reason of the rule is as forcible in its application to written reports presented in that body by its committees, to resolutions offered, which, though in writing, must be reproduced in speech, and to the act of voting, whether it is done vocally or by passing between the tellers. In short, to things

24. Coffin v. Coffin, 4 Mass. 1, 27 (1808). 
generally done in a session of the House by one of its members in relation to the business before it." 25

As in other cases of absolute privilege, neither malicious falsity nor bad motive will destroy its character. ${ }^{26}$ Some years ago an attempt was made to break the privilege of a United States Senator in an action for slander by alleging that he had uttered certain defamatory words concerning the plaintiff.

" in the chambers of the Senate of the United States... in the course of a speech but not in the course of a debate on the floor of the Senate . . . unofficially and not in the discharge of his official duties as a Senator of the United States . . . of and concerning a subject not then and there pertinent or relevant to any matter under inquiry by the said Senate of the United States, maliciously, wilfully, falsely and wrongfully . . .." ${ }^{27}$

The Court ruled that, despite the allegation of lack of pertinency, the words having been spoken in the course of a speech in the Senate, were absolutely privileged, saying:

"Under the declaration the words forming the basis of the plaintiff's action were uttered in the course of a speech in the chamber of the Senate of the United States, and were absolutely privileged and not subject to 'be questioned in any other place.' The averment that these words were spoken 'unofficially and not in the discharge of his official duties as a Senator' is a mere conclusion and entirely qualified by the averment that they were uttered in the course of a speech." 28

In the same case, the Court gave the following as its reason for placing a liberal construction upon the constitutional provision:

"It is manifest that the framers of the Constitution were of the view that it would best serve the interests of all the people if

25. Kilbourne v. Thompson, 103 U.S. 168, 204 (1880). Although this case was a contempt case, the legislative freedom of speech was used to support the power of Congress to punish for contempt. See Spalding v. Vilas, 161 U.S. 483 (1896) ; In re Chapman, 166 U.S. 661 (1897) ; Sinclair v. United States, 279 U.S. 263 (1929) ; Townsend v. United States, 95 F.2d 352 (D.C. Cir. 1938); United States v. Josephson, 165 F.2d 82 (2d Cir. 1947); Lawson v. United States, 176 F.2d 49 (D.C. Cir. 1949) ; Morford v. United States, 176 F.2d 54 (D.C. Cir. 1949). And see the noted classic judgment of Lord Chief Justice Ellenborough in Burdett $v$. Abbott 14 East., 1, 131 ef seq., 104 Eng. Rep. 501, 551 et seq., (1811). In harmony with the same trend is the rule giving absolute immunity to declarations of those exercising executive power: REsTATEMENT, ToRTS, \$ 591 (1938); Glass v. Ickes, 117 F.2d 273 (D.C. Cir. 1940); Jones v. Kennedy, 121 F.2d 40 (D.C. Cir. 1941); Barsky v. United States, 167 F.2d 241 (D.C. Cir. 1948). See Note, Scope of Absolute Privilege of Executive Officer, 132 A.L.R. 1340 (1941).

26. Yankwich, It's Liber or Contempt IF You PRINT It 292-297, 368 (1950).

27. Cochran v. Couzens, 42 F.2d 783 (D.C. Cir. 1930) (Emphasis added).

28. $I d$. at 784 . 
members of the House and Senate were permitted unlimitd freedom in speeches or debates. The provision to that end is, therefore, grounded on public policy, and should be liberally construed. Presumably legislators will be restrained in the exercise of such a privilege by the responsibilities of their office. Moreover, in the event of their failure in that regard, they will be subject to discipline by their colleagues. Article 1, Sec. 5." 29

Courts realize, in the words of Balthazar, that "slander lives upon succession" and may ". . . With foul intrusion enter in, And dwell upon your grave when you are dead." 30 Nevertheless, in protecting the right to legislate in a free society, courts disregard the occasional injury to individual reputation. They consider, in this light, not only this particular immunity, but the immunity of all governmental acts. As said by Justice Prettyman in a recent contempt case:

"The question presented by these contentions must be viewed in the light of the established rule of absolute immunity of governmental officials, Congressional and administrative, from liability for damage done by their acts or speech, even though knowingly false or wrong. The basis of so drastic and rigid a rule is the overbalancing of the individual hurt by the public necessity for untrammeled freedom of legislative and administrative activity, within the respective powers of the legislature and the executive." 31

The constitutional protection of legislative speech is, therefore, complete. Nearly seventy years ago Lord Chief Justice Coleridge summed it up in one sentence:

"What is said or done within the walls of Parliament cannot be inquired into in a court of law." 32

\section{IMMUNITY-FOR WHAT?}

The preceding analysis of the development of the principle of legislative immunity of speech and action indicates that it began as an assertion of a privilege by Parliament against the King. As parliamentary institutions gained in influence, the right, originally granted as a matter of grace by the King, achieved constitutional and statutory sanction. In this manner, it became a part of the common law of the American colonies, found its way into their legislative practices and

29. Ibid.

30. Shakespeare, Comedy of Errors, Act III, Scene 1.

31. Barsky v. United States, 167 F.2d 241 (D.C. Cir. 1948); and see United States v. Josephson, 165 F.2d 82 (2d Cir. 1947); compare the language of the supreme court of Ohio in Bigelow v. Brumley, 138 Ohio St. 574, 580-590, 37 N.E.2d 584, 589-592 (1941); and see REstateMENT, ToRTs, § 584 (1938).

32. Bradlaugh v. Gossett, 12 Q.B.D. 271,275 (1884). And see, Ex parte Wason, L.R. 4 Q.B. 573 (1869); Ex parte Herbert, 1 K.B. 594 (1935). 
was, finally, given full recognition by the federal and state constitutions. In truth, so far as the state governments are concerned, the right would probably be recognized to exist even if distinct constitutional statutory authority were absent. ${ }^{33}$ That its existence is an integral and indispensable part of modern legislative procedure in a free society cannot be questioned.

As a society becomes more complex, the legislative process-the means through which social control is exercised-assumes greater significance. While the form of its exercise and the instrumentalities through which it acts may change, the need for social controls will increase rather than diminish. Even totalitarian regimes dissociate legislation, to some extent, from executive control, although representation in the legislative body may be on a different basis, and the party ideology is all-dominating. ${ }^{34}$ For this reason protection of legislative speech and action, when confined to its legitimate aims, is, even today, and will continue to be, in the language of the Massachusetts Constitution of 1780 , "essential to the rights of the people". Its abuse may result in what one of its recent victims called, "ordeal by slander". 35 But the fact that a power may be abused or used oppressively "evidences no ground for denying the power". ${ }^{36}$ So, to abolish the privilege-as some have advocated-is not the remedy. It cannot be done constitutionally. Nor can strict legal limits be imposed. Moreover, in view of the significance of the right in the exercise of representative power in a free society, it should not be abolished or curtailed by lawe. But it should not be allowed to become a shield for base slander.

Vilification by senators is not new. In 1863, Senator Willard Saulsbury called President Lincoln "a weak and imbecile man". The Vice-President ordered the sergeant-of-arms to take the Senator in charge, when he continued to talk after being ordered to sit down. But when, during the presidency of Andrew Jackson, Charles Sumner, speaking of the President, said, "We have never before had a President of the United States who was an enemy of his country," the presiding officer of the Senate ruled that the Senator was not out of order, and the Senate sustained him.

33. 1 Story, Cominentaries on the Constiturton, $\$ 866$; (5th ed. 1891). 1 Cooley ToRTs, $\$ 154$ (4th ed. 1932). Both assert its existence as a constitutional right traceable to colonial days.

34. U.S.S.R. Consr., Art. III-XLII; MIRkIne-Guetzevitch, op. cit. supra note 8, at 267, 272. See Scrlesinger, Soviet Legal THeORY 60-61, 196-197 (1945); Towster, Political Power in the U.S.S.R. 343 et seq. (1948); Vyshinsky, The Law of the Soviet State et seq. (1948).

35. See Lattimore, Ordeal by Slander (1950); Lattimore, What It Was Like, 201 Harpers 43, 79 (Aug. and Sept. 1950).

36. McGrain v. Daugherty, 273 U.S. 135, 175 (1927). See Ex parte Hague, 105 N.J. Eq. 134, 150 At1. 322 (1929) ; 8 WrgMore, EvidenCE, $\$ 2195$ (3d ed. 1940). 
In May, 1879, Senator Zachariah Chandler, speaking of twelve senators, said: "By fraud and violence you occupy your seats." This language was held not to impute fraud or violence to the senators themselves. $^{37}$ And, more recently, in 1950 , when the confirmation of General George C. Marshall as Secretary of Defense came before the Senate, Senator William E. Jenner of Indiana called Marshall, "front man for traitors . . . a living lie... an unsuspecting stooge . . . or an actual co-conspirator." The New York Times of September 17, 1950, commented, "The speech so shocked the Senate that most decided not to 'dignify' it with a reply." Once more the Senate showed its hesitancy to control senatorial speech. On the whole, the Congress of the United States has not been consistent in censuring its members for calumniating language, even when addressed to members themselves. And it seems to have exercised little or no control over attacks by its members on outsiders. The right of the Congress to regulate and control the exercise of this privilege is implicit in the constitutional provision that, for speech or debate, the members shall not be questioned "in any other place." 38 There is also the right to punish a member for disorderly behavior and, by two-thirds vote, to expel him. ${ }^{39}$ On the other hand the English Parliament has been very strict in censuring and expelling members for unwarranted vilification in debate. It has also imposed the most abject forms of penance. ${ }^{40}$ But, while we have instances of expulsion from the Senate they involved members guilty of serious misconduct.

In July, 1797, Senator William Blount was expelled from the Senate for "a high misdemeanor, entirely inconsistent with his public trust and duty as a senator." The offense consisted of attempting to induce an American Agent among the Indians to disregard his duties. In commenting on the case, the Supreme Court notes:

"It was not a statutable offence nor was it committed in his official character, nor was it committed during the session of Congress, nor at the seat of government." 41

37. Luce, op. cit. supra note 5, at 511-512.

38. U.S. Const., Art. I, $\$ 6$, cl. 1 .

39. Id., Art. I, \& 5, cl. 2. See In re Chapman, 166 U.S. 161, 169 (1897) ; Kilbourn v. Thompson, 103 U.S. 168, 182 (1880). For the right of expulsion in colonial legislatures, see CIARKE, op. cit. supra note 6 , at 187-196; see references in notes 41 and 42 infra.

40. May, Partandentary Practice 52, 60-64, 440-441 (14th ed., Campion, 1946) ; WITTKE, op. cit. supra note 6 , at 30 ; REDLICH, op. cit. supra note 6 , at $71-$ 75 ; LUCE, op. cit. supra note 5 , at 275-292.

41. In re Chapman, 166 U.S. 661,670 (1897). The Blount case is reported in TAFT, Senate Eiection Cases, 929 (1903). A move to oust Senator John Smith of Ohio for his alleged participation in the conspiracy of Aaron Burr failed on April 8, 1808. The vote was 19 for and 10 against depriving the Senator of his seat. He resigned on April 9, 1808. Id. at 934-948. This case is interesting for the 
Senators from the Confederate states who withdrew from the United States Senate at the beginning of the War Between the States were also expelled. ${ }^{42}$ And in the House, many members voted, in October, 1921, to expel Representative Thomas L. Blanton of Texas for inserting scurrilous matter into the congressional record under leave to extend his remarks. But a sufficient number of votes not having been secured, he was reprimanded in a manner considered most humiliating. ${ }^{43}$

The above analysis demonstrates forcibly what many victims of Congressional vilification have learned through hard experience. The American Congress is neither consistent nor effective in intra-parliamentary sanction of members who give expression to private spites. What then shall the answer to the problem be?

\section{Proposed ReMedies}

The Tydings Sub-Committee recognized the injustice and fraud which, at times, the abuses of the immunity privilege made possible, and recommended a congressional study with a view of preventing their future recurrence. Its recommendation reads: "It is recommended that a joint committee of the House and Senate be appointed to make a careful study of the immunity from civil suit extended Members of Congress by reason of statements made by them on the floor of either House and before congressional committees. Our experience in this investigation indicates that this privilege extended us should not become a license for the character assassination of American citizens. It is believed that from such a study it may be possible to evolve legislation which is designed to preserve this immunity without prejudice to the historic and necessary reasons therefor and at the same time insure that it does not become a shield to perpetrate injustice and fraud." 44

Senator Lester C. Hunt of Wyoming, a former governor of that state, seems to be spearheading a movement in the Senate to deal concretely with the abuses of congressional immunity. He has introduced a constitutional amendment which would abolish the immunity. Aware, no doubt, of the objections which could be urged against the

reason that the committee of the Senate which recommended expulsion insisted that the right to expel, as exercised previously in the Blount case, is not "a sequel to the issue of a legal prosecution." Id. at 939 . It would seem that, early in our history, the Senate was inclined to consider the objectionable conduct of one of its members a challenge to the Senate's own integrity. The language used by John Quincy Adams for the Committee in the Smith case speaks eloquently for that view. See LUCE, op. cit. supra note 5, at 285-292.

42. TAFT, op. cit. supra note 41 , at 951-966.

43. LUCE, op. cit. supra note 5 , at 515-516.

44. Sen. Rep. No. 2108, 81st Cong., 2d Sess. 169 (1950). 
total abolition of the privilege, such as have been voiced in this article, and of the slow process of achieving the result by amending the United States Constitution, Senator Hunt has introduced a bill which would give one defamed by any member of the Congress the right to sue the Government. Senator Hunt would accomplish this by amending the Federal Tort Claims Act. This Act, adopted by the Congress on August 2, 1946, culminated a long struggle to secure abandonment on the part of the Government of the United States of its sovereign immunity to suit in tort cases. The Supreme Court characterized the Act as "the product of some twenty-eight years of congressional drafting and re-drafting, amendment and counter-amendment." 45 It allows actions to be brought

"for injury or loss of property, or personal injury or death caused by the negligent or wrongful act or omission of any employee of the Government while acting within the scope of his office or employment, under circumstances where the United States, if a private person, would be liable to the claimant in accordance with the law of the place where the act or omission occurred." 46

The Supreme Court has stated that the adoption of this Act and of others which, in the past, have waived sovereign immunity to stit, in special cases, "attests to the growing feeling of Congress that the United States should put aside its sovereign armor in cases where federal employees have tortiously caused personal injuries or property damage." 47 And, in view of its avowed purpose and legislative history, the Supreme Court has declined to apply to it the strict construction which is usually applied to statutes surrendering governmental rights. On the contrary, it has interpreted it as a broad consent to sue. ${ }^{48}$ In view of this attitude of the courts and of the liberal approach of the particular statute by which Senator Hunt would give redress against legislative defamation, no theoretical objection could be raised against making the Government responsible for legislative slander. An employer is responsible for the slander by an employee, if committed in the course of employment. The owner of a public place, such as a saloon, is held responsible for an assault by an employee. ${ }^{49}$ Newspapers are held accountable for the libelous statements of their reporters or editors or others which they disseminate.

45. United States v. Spelar, 338 U.S. 217, 219-20 (1949).

46. 28 U.S.C. $\$ 1346 \mathrm{~b}$. See Yankwich, Problems Under the Federal Tort Claims Act, 9 F.R.D. 143 (1949); Tooze, Uncle Sam-Tort-Feasor, 29 Ore. L. REv. 245 (1950).

47. American Stevedores v. Porello, 330 U.S. 446, 453 (1947).

48. United States v. Aetna Casualty \& Surety Co., 338 U.S. 366, 383 (1949).

49. Novick v. Gouldsberry, 173 F. 2d 496 (9th Cir. 1949). 
In a strict sense, the relationship of a legislator to the Government is not that of employer and employee. But, in a broader sense, the members of the Senate and House are our agents. And, in view of the trend expressed by the passage of the Federal Tort Claims Act and the English Crown Proceedings Act, which went into effect on January $1,1948,{ }^{50}$ there is as much reason for holding the Government (us all) responsible for the reckless slander of an innocent person by our legislative agents as there is for holding the Government (us all) responsible for the reckless driving of a postal employee. The wrong committed in both instances is a tort. It may be argued that we employ legislators to legislate, not to vilify. But so do we employ truck drivers to transport mail and other governmental property, not to inflict physical injury on others. Once we postulate the advisability of abandoning the doctrine of sovereign immunity, which in the United States has been considered as an anachronism, ${ }^{51}$ its extension to the grievous tort of presently protected slander is but a slight step in enforcing responsibility in Government, and giving redress against irresponsible exercise of governmental power or immunity.

The proposal may seem drastic. But Senator Hunt, evidently realizes that the abuses of legislative immunity endanger the free circulation of ideas by those who may be cowed by threats of untrammelled and privileged denunciation by an authoritarian legislator and interests who may be hiding behind him, determined to silence dissent.

Senator Hunt seems to think that the evil proportions which the abuse of the privilege has assumed, warrant drastic action. For he is quoted in the press as saying:

"If situations should confront us, when we . . . are no longer able to control our own members by the rules of society, justice, and fair play, then we must take drastic steps to control them." 52

This view commands respect and assent. The proposed legislation may not deter reckless legislators any more than the present tort claims act may deter reckless drivers. But laws have a way of establishing patterns of behavior. And recognition of liability may result in deterring abuses. Decency of conduct may become the proper thing, even for a legislator. And, as in the case of personal injuries, vindication. through court action may bring some recompense to the injured person. The Government, when sued, would be entitled to claim the qualified

50. $10 \& 11$ Geo. VI, c. 44 (1947).

51. See Borchard, Govermment Liability in Tort, 34 YALE L.J. 1, 4 (1924); Borchard, Government Responsibility in Tort, 36 YALE L.J. 1, 3 (1926).

52. 172 Nation 4 (1951). 
privilege and the right to fair comment, which newspapers and others have when dealing with comments on public men and public matters. ${ }^{53}$

Our Congress has not shown the inclination to correct the abuses of legislative immunity which the English Parliament has. And it is doubtful if, having neglected to use the power of discipline to correct the abuses, they will be ready to adopt so drastic a reform of their own ways. However, the very agitation for such a bill is a helpful sign and may be the way for abandoning, under the whip of public opinion, what Senator Hunt called "such high-handed and irresponsible actions."

But self-discipline exercised by the Senate itself would, in the last analysis, result in a more effective vindication of the person innocently accused than could be achieved by a money judgment. More, it would help establish a healthier pattern in these debates which would be beneficial to the legislative immunity itself, by retaining admitted historical values, while doing away with some of its excrescences. It would, in the words of the Tydings Sub-Committee:

"preserve this immunity without prejudice to the historic and necessary reasons therefor and at the same time insure that it does not become a shield to perpetrate injustice and fraud." 54

If the democratic way of life is to be maintained, it is our dutyto use the words of Bishop Francis J. McConnell-to maintain "a social atmosphere in which the man whom we call the prophet gets his chance to win a hearing." ${ }^{55}$ And he cannot have this chance if irresponsible legislators can, without fear of consequences, destroy him with calumny.

\section{The Public's Responsibility}

So our final hope is an enlightened, vigilant and aroused public opinion which will refuse to accept "guilt by mere accusation" in lieu of proof under the due process of the Anglo-American legal system, will actively aid those wrongfully accused, and will express its disapproval of abuse by legislators of this valuable privilege. For, free as it is now of all legal restraint, if it is allowed to go unchecked by due regard for the decencies of civilized behavior, it will help undermine the legislative process itself.

53. See Yankwich, op. cit. supra note 26, at 297, 323-329; Noel, Defamation of Public Officers and Candidates, 49 CoL. L. REv. 875 (1949); Yankwich, The Protection of Newspaper Comment on Public Men and Public Matters, 11 LA. L. Rev. 327 (1951).

54. See note 44 supra.

55. Quoted in Yankwich, Freedom of the Press in Prospect and Retrospect, 15 So. CAL. L. Rev. 322, 333 (1942). 
Totalitarian detractors-Fascist and Communist-may sneer at parliamentarianism. But to those of us who believe that its disappearance would mean a loss of desirable values which have made life under freedom richer and better, an impairment of the independent power to legislate by loss of confidence in it would constitute an undesirable weakening of the democratic ideal. This ideal and the values inherent in it are constantly under challenge from without by undemocratic and authoritarian power.

We should not tolerate their erosion by those acting under it, from within. Abuse and distortion of legislative immunity by foul, backwounding and unlimited calumny, if not remedied, may result in an erosion difficult, if not impossible, to reclaim. The risk should not be incurred for the sake of allowing irresponsible legislators to vilify and scourge with impunity. 